(c) 2018 - ISSN 1807-2577

\title{
Evaluation of the effect of chlorhexidine and sodium hypochlorite in adhesive cementation of fiber posts - in vitro study
}

\author{
Avaliação do efeito da clorexidina e do hipoclorito de sódio na cimentação \\ adesiva de pinos - estudo in vitro \\ Tainara CONTE $^{\mathrm{a} *}$ (1) Guilherme Schmitt de ANDRADE ${ }^{\mathrm{b}}$ (1) Ana Paula GADONSKIc (1) \\ Daniella Cristo SANTIN ${ }^{d}$ (1) Fabiana Scarparo NAUFEL ${ }^{a}$ (1) \\ aUNIOESTE - Universidade Estadual do Oeste do Paraná, Curso de Odontologia, Cascavel, PR, Brasil \\ bUNESP - Universidade Estadual Paulista, Instituto de Ciência e Tecnologia, Departamento de Materiais Odontológicos \\ e Prótese, São José dos Campos, SP, Brasil \\ 'UNICAMP - Universidade Estadual de Campinas, Faculdade de Odontologia de Piracicaba, Departamento de Prótese \\ Dental, Piracicaba, SP, Brasil \\ ¿USP - Universidade de São Paulo, Faculdade de Odontologia de Bauru, Departamento de Dentística Operatória, \\ Endodontia e Materiais Dentários, Bauru, SP, Brasil
}

\begin{abstract}
How to cite: Conte T, Andrade GS, Gadonski AP, Santin DC, Naufel FS. Evaluation of the effect of chlorhexidine and sodium hypochlorite in adhesive cementation of fiber posts - in vitro study. Rev Odontol UNESP. 2019;48:e20190020. https://doi.org/10.1590/1807-2577.02019
\end{abstract}

\begin{abstract}
Resumo
Introdução: A fixação de pinos de fibra de vidro é realizada através de um processo adesivo. Falhas podem ocorrer na adesão devido à degradação hidrolítica dos adesivos, ou pela degradação das fibras colágenas da camada híbrida por enzimas intrínsecas. Objetivo: Avaliar o efeito do tratamento com clorexidina e hipoclorito de sódio sobre a resistência de união adesiva à dentina. Material e método: Trinta raízes bovinas foram distribuídas aleatoriamente em 3 grupos $(n=10)$ : a) Controle, b) Clorexidina 2\% e c) Hipoclorito de Sódio 5\%. Após, para a cimentação do pino radicular, utilizou-se o cimento resinoso RelyX $^{\circledR}$ ARC. Cada espécime resultou corpos-de-prova dos três terços radiculares, os quais foram submetidos ao teste de pushout (MPa) nos períodos de 24 horas e 12 meses. Valores de resistência de união foram analisados pelos testes de Kolmogorov-Smirnov, ANOVA (three-way) e de Tukey. Analisou-se ainda o modo de fratura do pino, através de estereomicroscopia. Resultado: Não houve diferenças significativas entre tratamento no tempo imediato $(\mathrm{p}=0,0644)$ ou na interação dos fatores $(\mathrm{p}=0,1935)$. Após um ano, os grupos experimentais não promoveram diferença significante na resistência de união em relação ao controle, com exceção do terço cervical do grupo clorexidina, onde houve uma perda significativa de adesão. Quanto ao modo de fratura, houve predominância do tipo mista em todos os grupos e terços. Conclusão: 0 uso de clorexidina ou hipoclorito não promove benefícios ou prejuízos na resistência de união adesiva de pinos de fibra, mas há influência dos terços radiculares, sendo a pior resistência de união no terço apical.
\end{abstract}

Descritores: Cimentação; pinos dentários; cimentos de resina; clorexidina; hipoclorito de sódio.

\begin{abstract}
Introduction: The attachment of fiberglass posts is achieved through an adhesive process. Failures in adhesion may occur due to the hydrolytic degradation of the adhesives, or to the degradation of the collagen fibres of the hybrid layer by intrinsic enzymes. Objective: To evaluate the effect of chlorhexidine and sodium hypochlorite treatment on bond strength to dentin. Material and method: Thirty bovine roots were randomly distributed into 3 groups (n=10): a) Control, b) 2\% Chlorhexidine, and c) 5\% Sodium Hypochlorite. Next, RelyX ${ }^{\circledR}$ ARC resin cement was used to cement the post. Each specimen resulted in samples from the three root thirds that were submitted to the pushout test (MPa) at 24 hours and 12 months. Bond strength values were analysed using the Kolmogorov-Smirnov, 3-way ANOVA and Tukey tests. The fracture mode of the pin was also analysed using stereomicroscopy. Result: There were no significant differences between treatments at the immediate time $(\mathrm{p}=0.0644)$ or in the interaction of factors
\end{abstract}


$(\mathrm{p}=0.1935)$. After one year, the experimental groups showed no significant differences in bond strength in relation to the control group, with the exception of the cervical third of the chlorohexidine group in which there was a significant loss of adhesion. As for the fracture mode, there was a predominance of the mixed type in all groups and thirds. Conclusion: The use of chlorhexidine or hypochlorite provides neither benefits nor losses in the adhesive bond strength of fiberglass posts. However, there is an influence of the root thirds, with the worst bond strength in the apical third.

Descriptors: Cementing; dental posts; resin cements; chlorhexidine; sodium hypochlorite.

\section{INTRODUCTION}

The adhesion of restorative materials to the dentin substrate is not perfectly stable in the oral environment. Regardless of the adhesive system used, there is degradation over time ${ }^{1}$. Adhesive systems have hydrophilic monomers, which are intended to promote greater compatibility with the moist substrate that is the dentin ${ }^{2}$. The more hydrophilic the monomers, the more water sorption they suffered. This leads to hydrolytic degradation of the resins ${ }^{3}$. Another factor that may compromise the adhesive restorations is the degradation of the collagenous fibers in the hybrid layer, caused by enzymes intrinsic to dentin ${ }^{4}$. The intraradicular attachment of the fiberglass posts as a retentive resource in endodontically treated teeth, is done through an adhesive process. The good performance of adhesive systems and resin cements, necessary for proper anchoring of the post, are fundamental to the success of the technique.

Fiberglass posts are retaining devices, used more and more frequently in clinical practice, intended to aid in the retention of restorations of extensively damaged teeth. Their good translucence favors esthetics, in addition to providing high resistance to fatigue and flexion, a modulus of elasticity similar to the dentin and good biological compatibility. These features favor its use ${ }^{5}$.

The hybridization process results from infiltration of the primer into the open spaces and into the interior of the collagen matrix, exposed by demineralization of the dentin ${ }^{6,7}$. The spaces between the collagen fibers are wide enough to allow penetration of the monomers present in the primers. However, the intermolecular spaces in the lateral chains of collagen fibers that should also be occupied by the monomers are not, as these spaces are smaller than them ${ }^{6}$. Parallel to the degradation of the organic matrix of the adhesive materials, these unfilled spaces contribute to the deterioration of the hybrid layer. The collapse of the collagen matrix, particularly one that is poorly infiltrated by the monomers, occur due to proteolytic degradation, caused by the action of intrinsic dentin enzymes called metalloproteinases (MMPs) and cysteine cathepsins (CTs) ${ }^{4}$. Exposure of the organic matrix of the dentin by acid etching can also activate these enzymes ${ }^{8}$. Thus, they are one of the factors responsible for the degradation of the hybrid layer leading to failures of the adhesive restorations ${ }^{8}$. Different strategies have been proposed to avoid this biodegradation, such as the use of MMP inhibitors and the removal of collagen exposed by demineralization ${ }^{9}$.

There is strong evidence of the use of chlorohexidine (CHX) to inhibit MMPs and CTs ${ }^{9,10}$. This inhibition is due to the chelating effect of this substance, which sequesters ions (calcium and zinc) necessary for the activity of the MMPs ${ }^{8}$. Meanwhile, its effect on the CTs is due to its high degree of affinity for the molecule, blocking the catalytic domain of the enzymes and rendering them unfit for their genolytic activity ${ }^{11}$.

The use of sodium hypochlorite $(\mathrm{NaOCl})$ for deproteinization of the demineralized surface of the dentin, prior to the adhesive, is intended to bypass the difficulty of obtaining maximum infiltration of the adhesives in the fibrils ${ }^{12}$. Thus, the removal of the exposed collagen not only reduces the sensitivity of the technique but also allows for a more porous surface, similar to that of the conditioned enamel ${ }^{13}$. Another justification is that deproteinization provides wider tags with lateral ramifications that would provide greater retention of the adhesive ${ }^{14,15}$. The $\mathrm{NaOCl}-$ 
treated dentin is rich in exposed hydroxyapatite crystals ${ }^{16}$ and may result in a more stable interface over time since it becomes, essentially, mineral ${ }^{17}$.

In order to reduce intraradicular pin displacement failures and to prolong the longevity of teeth restored with this apparatus, studies are conducted to investigate the performance of different dental substrate treatments in order to obtain greater durability and efficacy of the adhesive interface ${ }^{18-20}$. Studies have investigated the action of $\mathrm{CHX}^{19,21-23}$ and $\mathrm{NaOCl}^{24}$ on root dentin, in order to maintain the integrity of the hybrid layer. These have reduced the proteolytic activity, although they have not shown effective results regarding the strength of the adhesive bond ${ }^{19,24}$.

The aim of the present study was to assess the effect of $\mathrm{CHX}$ and $\mathrm{NaOCl}$, following acid conditioning of the dentin, on the bond strength (BS), both immediately and after 12 months, on the adhesive cementing of the fiberglass posts in the three thirds of the root canal. The null hypotheses tested in the present study are: I) the use of $\mathrm{CHX}$ and $\mathrm{NaOCl}$ does not affect the bond strength, immediately and after 12 months, of adhesive cementing of fiberglass posts; and, II) the root thirds do not affect the bond strength, immediately and after 12 months, of adhesive cementing of fiberglass posts.

\section{MATERIAL AND METHOD}

\section{Experimental Design}

The design of the present study was taken from a 3x3x2 factorial experimental design. The factors of this study are: 1) 3-level treatment: a) control group with acid conditioning, adhesive and dual cement; b) $2 \%$ chlorohexidine, following acid conditioning; c) $5 \%$ sodium hypochlorite, following acid conditioning; 2) Root third, in 3 levels: a) Cervical (CT), b) Middle (MT) and Apical (AT); 3) Time, in 2 periods: a) 24 hours (immediately) and b) 12 months.

The first specimens of each third were stored in an oven at $37^{\circ} \mathrm{C}$ (Estufa 502, Fanem, São Paulo, SP, Brazil), to be tested after 12 months. The variable tested was adhesive BS, evaluated using a mechanical test for extrusion (push-out) force (MPa).

\section{Root Selection}

To do the bond strength push-out test, 30 roots of the inferior incisors of bovines, slaughtered for reasons other than research, were donated to the researchers and used.

After cleaning, using periodontal curettes and pumice paste with a Robson brush, the teeth were selected in such a way as to obtain 30 recently extracted bovine roots. This allowed the selection of similar units with cylindrical conduits and diameter compatible with the post to be used. The bovine teeth were kept in a $0.5 \%$ Chloramine solution for a maximum of 1 month at $4^{\circ} \mathrm{C}$ following extraction.

The coronal portions were discarded after cutting in the region of the cement-enamel junction, perpendicular along the axis of the tooth, using a hand-held, double-faced diamond disk (KG\#7020, KG Sorensen, Cotia, SP, Brazil) under continuous irrigation. At the end of this section, a standardized root length of $17 \mathrm{~mm}$ was obtained and the roots were stored in deionized water at $4^{\circ} \mathrm{C}$. 


\section{Preparation of the Teeth}

Preparation of the roots was accomplished using a \#45 Kerr endodontic file (Dentsply, Maillefer, Ballaigues, Switzerland), with a $16 \mathrm{~mm}$ standardized working distance. The conduits were irrigated using deionized water, avoiding interference from possible variation factors by using available oxidizing irrigation materials. These were prepared using Gates Glidden drills, numbers 1, 2 and 3 consecutively, and then Largo drills, numbers 4, 5 and 6 , so that the diameter of the conduit was standardized. At the end of the preparation, the roots were immersed in deionized water and submitted to cleaning in an ultrasonic cube for 5 minutes. Then, the conduits were irrigated using deionized water and dried using absorbent paper cones (Tanari, Manacapuru, AM, Brazil).

After 24 hours, a smooth, \#2 cone-shaped post was cemented into each root. The posts consisted of fiberglass filaments immersed in an epoxy resin matrix with a metallic stem in the center of the structure (Exacto, Ângelus, Londrina, PR, Brazil).

\section{Distribution of Roots into Groups}

The roots were numbered and randomly distributed into 3 groups $(n=10)$, using a computer program ${ }^{25}$, according to the treatments (Figure 1).

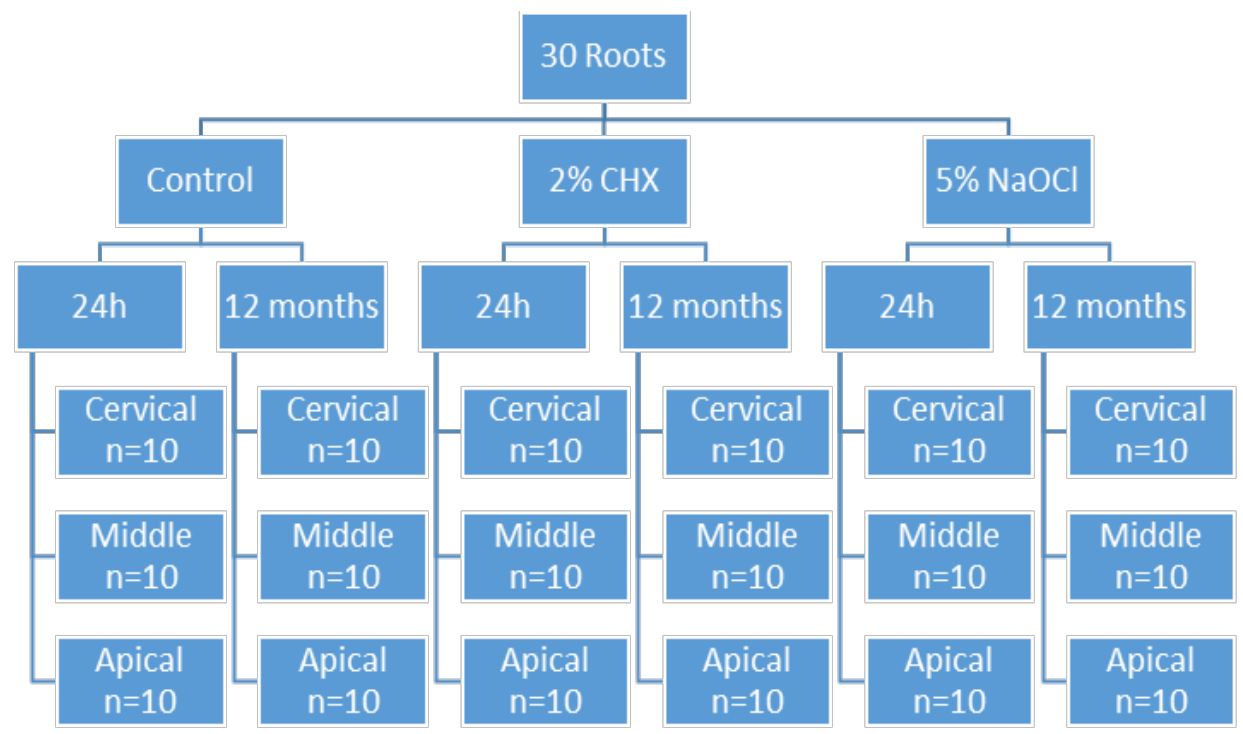

Figure 1. Distribution of roots into groups according to treatment and time.

Each specimen provided three samples of each of the three root thirds. One sample of each third was tested $24 \mathrm{~h}$ after cementing and another was tested after 12 months; the third sample obtained from each third was used for further long-term evaluation.

\section{Preparation of the Posts and Conduits for Adhesive Cementing}

The fiberglass posts were cleaned using $70 \%$ ethyl alcohol and then silanized using silane Primer (Angelus, Londrina, PR, Brazil), allowing the solvent to evaporate for 1 minute. The composition of the phosphoric acid, adhesive system and resin cement used is described in Table 1. 
Table 1. Composition of materials used

\begin{tabular}{|c|c|c|c|}
\hline Material & Manufacturer & Composition & Classification \\
\hline $\begin{array}{l}\text { 37\% phosphoric acid } \\
\text { Fusion-Duralink }^{\circledR}\end{array}$ & $\begin{array}{c}\text { Angelus, Londrina, PR, } \\
\text { BRA }\end{array}$ & $\begin{array}{l}\text { Orthophosphoric acid; } \\
\text { water; thickener and } \\
\text { pigments; }\end{array}$ & Acid conditioning agent \\
\hline Adper ${ }^{\circledR}$ Single Bond 2 & 3M ESPE, St Paul, MN, EUA & $\begin{array}{c}\text { Silica nanoparticle, } \\
\text { BisGMA, HEMA, } \\
\text { dimethacrylates, ethanol, } \\
\text { water, an innovative } \\
\text { photo-initiating system } \\
\text { and a functional } \\
\text { polyacrylic and } \\
\text { polyalkenoic acid } \\
\text { methacrylate copolymer }\end{array}$ & $\begin{array}{c}\text { Conventional } \\
\text { photopolymerizable } \\
\text { adhesive system } \\
\text { (condition / washer type), } \\
\text { single component } \\
\text { ('primer' and adhesive } \\
\text { together) }\end{array}$ \\
\hline RelyX ${ }^{\circledR}$ ARC & 3M ESPE, St Paul, MN, EUA & $\begin{array}{l}\text { Silica-treated with silicon, } \\
\text { dimethacrylate of 2.2- } \\
\text { ethylenedioxyethyl, } \\
\text { methacrylate of bisphenol } \\
\text { diglycidyl, ether, } \\
\text { functionalized } \\
\text { dimethacrylate polymer }\end{array}$ & Dual resin cement \\
\hline
\end{tabular}

The following cementing protocol was carried out to cement the posts: following irrigation of the conduit with deionized water and drying with absorbent paper cones, 37\% phosphoric acid was applied to the interior of the conduit for $15 \mathrm{~s}$, followed by irrigation with water for $30 \mathrm{~s}$. Following the acid conditioning, the conduits were dried with an absorbent paper cone. For the CHX experimental group, 2\% chlorhexidine digluconate (Maquira Dental Products, Maringá, PR, Brazil) was applied for $60 \mathrm{~s}$. At the same time, the $\mathrm{NaOCl}$ group used $5 \%$ sodium hypochlorite, applied under agitation for 2 minutes. The agitation was performed by manually vibrating a $\mathrm{K}$ \#15 file inside the conduit. After applying the pre-treatment to both groups, the conduit was irrigated using deionized water for $15 \mathrm{~s}$, followed by drying with absorbent paper cones. Manipulation of the cement occurred for 10s, according to manufacturer's recommendation, on a glass plate using a \# 24 spatula. The spatulated material was then taken to the conduit in excess using a Centrix ${ }^{\circledR}$ syringe with metal points for endodontic access ${ }^{26}$. Then there was the installation of the post, removal of excess cement and photoactivation using a Valo ${ }^{\circledR}$ (Ultradent Product, Inc., Indaiatuba, SP, Brazil) device for 60s.

\section{Obtaining the Specimens}

After cementing, the specimens were kept in deionized water at $37^{\circ} \mathrm{C}$ (Estufa 502, Fanem, São Paulo, SP, Brazil) for 48 hours. Then, the roots were sectioned perpendicular to their long axis using a diamond disk (Extex Corp., London, England) in a Labcut 1010 (Extec Corp., London, England) cutting machine. This was performed under constant irrigation, obtaining 9 slices (samples) of $1 \pm 0.2 \mathrm{~mm}$ thickness. The slices obtained were divided and individually identified according to the three root thirds (cervical, middle and apical), and these samples were stored in deionized water at $37^{\circ} \mathrm{C}$ (Estufa 502, Fanem, São Paulo, SP, Brazil) for 24 hours. One sample from each third was stored in the same oven to be aged for 12 months. 


\section{Adhesive Bond Strength Test (Mechanical Test - Push-out)}

The samples were submitted to the mechanical test by push-out force, after 24 hours and 12 months. They were positioned on a stainless-steel, metallic support containing a central perforation of $2 \mathrm{~mm}$ diameter. Due to the conical shape of the conduit, the load was applied in the apical-cervical direction, such that the post was pushed toward the widest portion of the conduit. The load was applied only to the surface of the post and the cement, without contact with the root dentin, such that there was no touching of the adhesive interface. Stainless steel tips having diameters ranging from $1.3 \mathrm{~mm}$ to $0.8 \mathrm{~mm}$ were used for this step, according to the diameter of the conduit in each slice, coupled to the universal testing machine (EMIC DL 2000, EMIC Equipamentos e Sistemas de Ensaio Ltda, São José dos Pinhais, PR, Brazil). The load cell used was $500 \mathrm{Kgf}(50 \mathrm{~N})$, at a speed of $1.0 \mathrm{~mm} / \mathrm{min}$.

\section{Conversion of Values}

The values obtained from the test were recorded in Kgf and, subsequently, converted to MPa. The formula used to calculate the bond strength was: $\alpha=F / A$, where $F$ is the force recorded at the moment of adhesive rupture (Kgf) and A is the area of the adhesive interface $\left(\mathrm{mm}^{2}\right)^{18}$. Since each sample had a cone-shaped adhesive area, the thickness of the slice and the diameter of the conduit were measured on both sides. A digital caliper (Messen Sensor Technology Co, Guangdong China) was used in this step.

The following formula was used to calculate the adhesive interface area in $\mathrm{mm}^{2}: \mathrm{A}=\pi(\mathrm{R} 2+\mathrm{R} 1)$ $\left[\mathrm{h}^{2}+(\mathrm{R} 2-\mathrm{R} 1)^{2}\right]^{0,5}$, where $\pi=3.14 ; \mathrm{R} 2=$ cervical radius of the cemented area; $\mathrm{R} 1=$ apical radius of the cemented area; and, $\mathrm{h}=$ height of the slice ${ }^{18}$.

\section{Fracture Mode Analysis}

The failure modes were analyzed in all of the specimens, using digital optical microscopy (Dino-Lite Premier, Anmo Electronics Corporation, New Taipei City, Taiwan) with 100\% magnification. The failures were classified as: I. Adhesion between the fiberglass post and the resin cement (without visible cement around the post); II. Mixed with resin cement covering the surface of the post; III. Adhesive between the resin cement and the root canal (post encased in resin cement); IV. Dentin cohesive.

\section{Statistical Analysis}

The data were tabulated and their normality verified using the Kolmogorov-Smirnov test $(\mathrm{p}<0.05)$. The $3 \times 3 \times 2$ factorial ANOVA test for subdivided parts $(5 \%)$ was performed for the normal and homogenous distribution of the data. In case of statistically significant differences, the complementary Tukey test (5\%) was performed.

\section{RESULT}

\section{Bond Strength Analysis}

Table 2 summarizes the values of the means and standard deviations relative to the adhesive BS, immediately and after 12 months. The results show statistical significance for the isolated factors time and root thirds $(\mathrm{p}<0.01)$, in addition to the triple interaction among time $\mathrm{x}$ root thirds 
$x$ treatment $(\mathrm{p}<0.05)$. The application of the complementary Tukey test showed that the immediate BS for the control group was equally superior in the cervical and middle thirds compared to the apical third.

Table 2. Means and standard deviations (SD) of adhesive bond strength (MPa), immediately and after 12 months, for the three factors studied

\begin{tabular}{|c|c|c|c|c|}
\hline Time & Treatment & Cervical Third & Middle Third & Apical Third \\
\hline \multirow{3}{*}{ 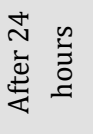 } & Control & $11.32(4.79) \mathrm{abA}$ & $9.29(5.48) \mathrm{aA}$ & $3.36(3.31) \mathrm{aB}$ \\
\hline & Chlorhexidine & $16.62(6.43) \mathrm{aA}$ & $9.23(5.55) \mathrm{aB}$ & $4.15(3.38) \mathrm{aC}$ \\
\hline & Sodium hypochlorite & $15.42(3.86) \mathrm{aA}$ & $9.234(4.72) \mathrm{aB}$ & $7.45(5.12) \mathrm{aB}$ \\
\hline \multirow{3}{*}{ 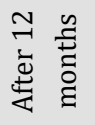 } & Control & $10.99(5.08) \mathrm{abA}$ & $4.11(2.43) \mathrm{aB}$ & $3.25(3.15) \mathrm{aB}$ \\
\hline & Chlorhexidin & $9.01(5.74) \mathrm{bA}$ & $5.70(2.84) \mathrm{aAB}$ & $3.26(3.03) \mathrm{aB}$ \\
\hline & Sodium hypochlorite & $12.10(5.43) \mathrm{abA}$ & $7.75(4.58) \mathrm{aA}$ & $2.05(1.71) \mathrm{aB}$ \\
\hline
\end{tabular}

Different lower-case letters in columns and upper-case in rows indicate statistically significant differences $(\mathrm{p}<0.05)$.

After 24 hours, there was no statistically significant difference for the treatment factor. However, significant values were found for the root thirds variable. For the control group, although the values between the CT and MT were equal, they differed from the AT which presented the lowest values. For the group treated with CHX and tested immediately, all the thirds showed statistically significant differences: the highest values of BS were in the CT, followed by the MT; and the lowest values were in the AT. Regarding the group treated with $\mathrm{NaOCl}$, during the same period, the results of the present study showed that the BS in the CT was statistically higher in relation to the MT and the AT, that did not differ from each other.

After 12 months of aging, there was a change in the BS in all treatments as well as in the root thirds. For the control group, a greater BS was found in the CT than in the MT and AT, which did not differ from each other. During the same period, the CHX group (9.01 MPa) and the $\mathrm{NaOCl}$ group (12.10 MPa) showed no significant difference in the BS in relation to the control group $(10.98 \pm 5.08)$. However, in the CT, the first group showed a significant reduction in BS, such as occurred in the second group, although on the AT.

\section{Fracture Pattern Analysis}

The fracture pattern in the present study was mainly of the mixed type, in all groups and in all thirds. This was followed by the presence of fracture at the cement and dentin interface, except for the CT in the CHX group (Figure 2). No cohesive type fracture was found in the dentin in any of the groups analyzed. 


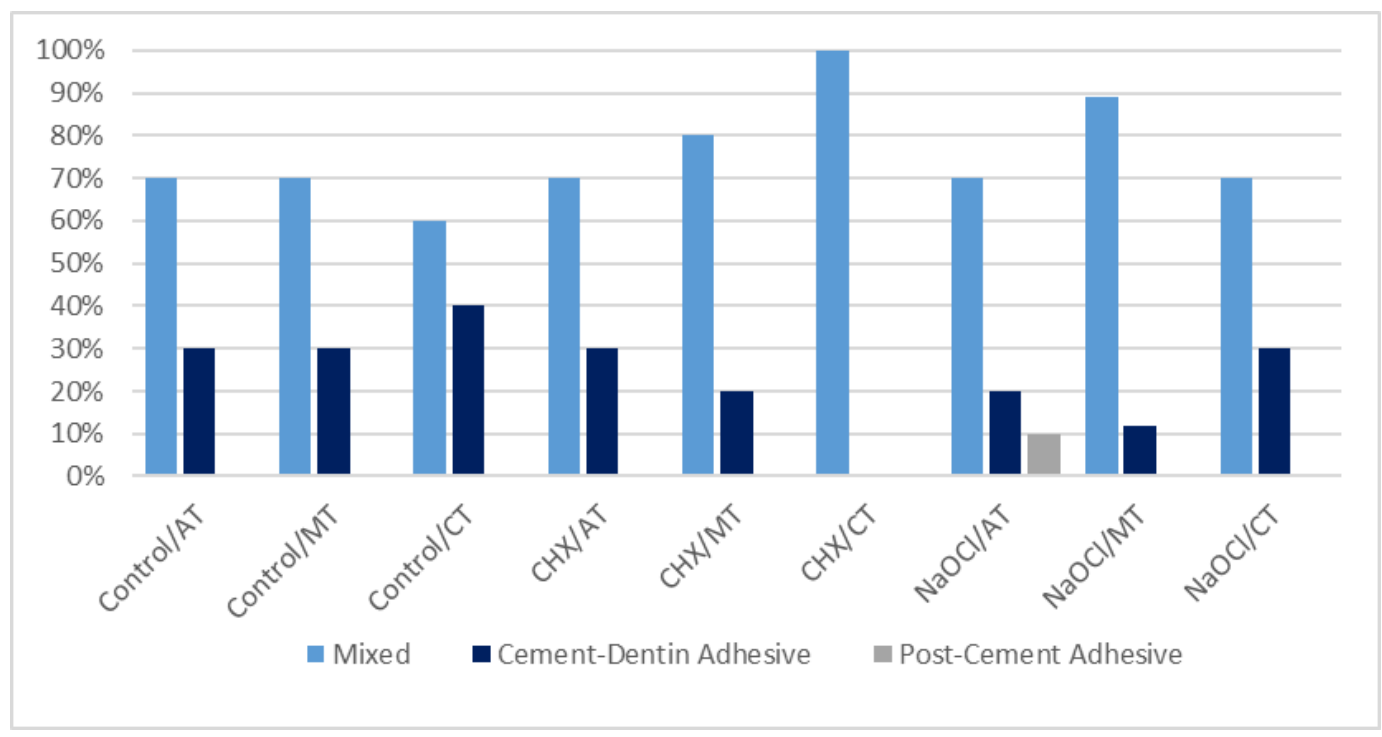

Figure 2. Predominance of fracture patterns.

\section{DISCUSSION}

The null hypothesis, regarding the factor treatment with $\mathrm{CHX}$ and $\mathrm{NaOCl}$, was partially rejected because the data obtained show that the treatment factor showed no statistically significant differences ( $\mathrm{p}=0.0644)$. The treatments with $\mathrm{CHX}$ and $\mathrm{NaOCl}$, in the short term, neither improved nor negatively affected the adhesive BS of the posts. This is probably due to the fact that the reduced proteolytic activity of the MMPs and the CTs has been seen in the increase of the adhesive BS in medium-/long-term studies. This improvement, however, cannot be detected easily in the immediate results, especially in the root canals ${ }^{19}$.

In the present study, no improvement in the BS was found for the groups treated with $\mathrm{NaOCl}$, which is similar to the findings by Saraiva et al. ${ }^{20}$ and Lindblad et al. ${ }^{21}$. Those studies also found no improvement in the results of adhesive BS in root canals. The first authors, however, used $\mathrm{NaOCl}$ prior to acid conditioning of the dentin, differing from the present study. In the study by Martinho et al. ${ }^{24}$, deproteinization reduced the adhesive BS and the authors claim that removal of the collagen network would influence the adhesion negatively, which was not verified in the present study.

Wang et al. ${ }^{19}$ found, using the push-out test, that there was no immediate BS improvement in the samples treated with $2 \%$ chlorhexidine after acid conditioning. However, there was improvement when the chlorhexidine was applied after the self-conditioning primer. This fact suggests that the HEMA monomers, present in the self-conditioning adhesives, may also inhibit collagen breakdown, probably through absorption by the MMPs, facilitating and prolonging the inhibitory effect of the $\mathrm{CHX}^{8}$.

Carrilho et al. ${ }^{10}$, in an in vitro experiment of adhesion on coronal dentin, used CHX after acid conditioning. Their microtensile test showed no increase in immediate BS. However, after 6 months of storage, it was found that CHX promoted approximately $23.4 \%$ greater BS than in the control group.

The second hypothesis, regarding the root thirds, was rejected because there was statistical difference for the thirds factors in both periods, immediately and after 12 months. The best results for $\mathrm{BS}$, in the control groups in both periods, and immediate $\mathrm{CHX}$ and $\mathrm{NaOCl}$, were in the cervical third. This result may be explained by the fact that it is more difficult to carry cement to the apical region and by the lower incidence of light, in addition to the irregular disposition of the dentinal tubes in the region ${ }^{19}$. These data corroborate the study by Wang et al. ${ }^{19}$ in which the 
efficacy of CHX on adhesive BS was more evident in the coronal dentin. The data disagree with Collares et al. ${ }^{22}$ who found stronger results for adhesive BS in root canals, compared to the coronal dentin, following treatment with CHX.

In the present study, after 12 months of storage, there was a reduction of BS in all groups, and it was greater in the group treated with CHX. Studies have shown that the application of $2 \%$ chlorhexidine to the dentin results in the formation of chlorine precipitates ${ }^{27}$. These precipitates are products of the reaction between $\mathrm{CHX}$ and phosphate ions present in dentin hydroxyapatite which slowly precipitate out of the solution ${ }^{28}$. The presence of these chlorine salts on the dentin wall would reduce the close contact and penetration of the adhesive system and of the cementing agent with the root surface ${ }^{29}$. The reducton of the BS may also be explained by the action of the CHX, temporarily inhibiting the action of the enzymes. However, after 12 months of storage, its function may have been eliminated, permiting degradation of the collagen fibers of the hybrid layer, thus reducing the adhesive strength ${ }^{21}$.

Contrary to the results found in the present study, Mendes et al. ${ }^{30}$ showed predominance of adhesive fracture between cement and post. According to their methodology, however, the posts were previously cleaned with phosphoric acid. The prevalence of adhesive fracture may still be attributed to various factors such as dentin, debris remaining on the canal walls after instrumentation and the lack of additional surface treatment during cementing 31 .

The use of adhesive materials is more challenging in root canals. The high $\mathrm{C}$ factor, the lower light penetration and lower degree of polymer conversion, reduce the adhesive BS when compared to the coronal portion. Therefore, it is important that more studies be conducted in order to advance adhesive procedures in this substrate, reducing the risk of short- and long-term failure ${ }^{23}$.

\section{CONCLUSION}

In the cervical third, the immediate effect of chlorhexidine and $\mathrm{NaOCl}$ was greater. However, they did not differ significantly from the control and, compared to the end (12 months), it was the chlorhexidine group that presented the lowest cervical value. Considering the limitations and the parameters of the present study, it may be concluded that, at the initial moment, the use of CHX or $\mathrm{NaOCl}$ does not provide benefits or damages to adhesive bond strength in the adhesive cementing of fiberglass posts. However, they do influence the root thirds, and the results of the present study show a superiority of the bond strength of the cervical third in relation to the others, regardless of time and/or treatment.

\section{REFERENCES}

1. Mjör IA, Moorhead JE, Dahl JE. Reasons for replacement of restorations in permanent teeth in general dental practice. Int Dent J. 2000 Dec;50(5):361-6. http://dx.doi.org/10.1111/j.1875595X.2000.tb00569.x. PMid:11197194.

2. El-Deeb HA, Al Sherbiney HH, Mobarak EH. Bond durability of adhesives containing modifiedmonomer with/without-fluoride after aging in artificial saliva and under intrapulpal pressure simulation. Oper Dent. 2013 Jan-Feb;38(1):48-56. http://dx.doi.org/10.2341/11-389-L. PMid:22770483.

3. Carrilho MR, Carvalho RM, Tay FR, Yiu C, Pashley DH. Durability of resin-dentin bonds related to water and oil storage. Am J Dent. 2005 Dec;18(6):315-9. PMid:16433398.

4. Tjaderhane L, Nascimento FD, Breschi L, Mazzoni A, Tersariol IL, Geraldeli S, et al. Optimizing dentin bond durability: control of collagen degradation by matrix metalloproteinases and cysteine cathepsins. Dent Mater. 2013 Jan;29(1):116-35. http://dx.doi.org/10.1016/j.dental.2012.08.004. PMid:22901826. 
5. Dietschi D, Duc 0, Krejci I, Sadan A. Biomechanical considerations for the restoration of endodontically treated teeth: a systematic review of the literature--part 1. Composition and micro- and macrostructure alterations. Quintessence Int. 2007 Oct;38(9):733-43. PMid:17873980.

6. Pashley DH, Tay FR, Breschi L, Tjäderhane L, Carvalho RM, Carrilho M, et al. State of the art etch-andrinse adhesives. Dent Mater. 2011 Jan;27(1):1-16. http://dx.doi.org/10.1016/j.dental.2010.10.016. PMid:21112620.

7. Nakabayashi N, Nakamura M, Yasuda N. Hybrid layer as a dentin-bonding mechanism. J Esthet Dent. 1991 Jul-Aug;3(4):133-8. http://dx.doi.org/10.1111/j.1708-8240.1991.tb00985.x. PMid:1817582.

8. Vaidyanathan TK, Vaidyanathan J. Recent advances in the theory and mechanism of adhesive resin bonding to dentin: a critical review. J Biomed Mater Res B Appl Biomater. 2009 Feb;88(2):558-78. http://dx.doi.org/10.1002/jbm.b.31253. PMid:18975378.

9. Osorio R, Yamauti M, Osorio E, Ruiz-Requena ME, Pashley D, Tay F, et al. Effect of dentin etching and chlorhexidine application on metalloproteinase-mediated collagen degradation. Eur J Oral Sci. 2011 Feb;119(1):79-85. http://dx.doi.org/10.1111/j.1600-0722.2010.00789.x. PMid:21244516.

10. Carrilho MR, Carvalho RM, Sousa EN, Nicolau J, Breschi L, Mazzoni A, et al. Substantivity of chlorhexidine to human dentin. Dent Mater. 2010 Aug;26(8):779-85.

http://dx.doi.org/10.1016/j.dental.2010.04.002. PMid:20472282.

11. Scaffa PM, Vidal CM, Barros N, Gesteira TF, Carmona AK, Breschi L, et al. Chlorhexidine inhibits the activity of dental cysteine cathepsins. J Dent Res. 2012 Apr;91(4):420-5. http://dx.doi.org/10.1177/0022034511435329. PMid:22266526.

12. Uceda-Gómez N, Loguercio AD, Moura SK, Grande RH, Oda M, Reis A. Long-term bond strength of adhesive systems applied to etched and deproteinized dentin. J Appl Oral Sci. 2007 Dec;15(6):475-9. http://dx.doi.org/10.1590/S1678-77572007000600004. PMid:19089183.

13. Wakabayashi Y, Kondou Y, Suzuki K, Yatani H, Yamashita A. Effect of dissolution of collagen on adhesion to dentin. Int J Prosthodont. 1994 Jul-Aug;7(4):302-6. PMid:7993540.

14. Vargas MA, Cobb DS, Armstrong SR. Resin-dentin shear bond strength and interfacial ultrastructure with and without a hybrid layer. Oper Dent. 1997 Jul-Aug;22(4):159-66. PMid:9484156.

15. Perdigão J, Lopes M, Geraldeli S, Lopes GC, García-Godoy F. Effect of a sodium hypochlorite gel on dentin bonding. Dent Mater. 2000 Sep;16(5):311-23. http://dx.doi.org/10.1016/S01095641(00)00021-X. PMid:10915892.

16. Erhardt MC, Osorio E, Aguilera FS, Proença JP, Osorio R, Toledano M. Influence of dentin acid-etching and NaOCl-treatment on bond strengths of self-etch adhesives. Am J Dent. 2008 Feb;21(1):44-8. PMid:18435376.

17. Toledano M, Perdigão J, Osorio E, Osorio R. Influence of $\mathrm{NaOCl}$ deproteinization on shear bond strength in function of dentin depth. Am J Dent. 2002 Aug;15(4):252-5. PMid:12572644.

18. Chaves LP, Ciantelli TL, Araújo DFG, Giacomini MC, Tjäderhane L, Scaffa PMC, et al. How proteolytic inhibitors interact with dentin on glass-fiber post luting over 6 months. J Mech Behav Biomed Mater. 2018 Mar;79:348-53. http://dx.doi.org/10.1016/j.jmbbm.2018.01.011. PMid:29358152.

19. Wang L, Pinto TA, Silva LM, Araújo DF, Martins LM, Hannas AR, et al. Effect of $2 \%$ chlorhexidine digluconate on bond strength of a glass-fibre post to root dentine. Int Endod J. 2013 Sep;46(9):847-54. http://dx.doi.org/10.1111/iej.12070. PMid:23441932.

20. Saraiva LO, Aguiar TR, Costa L, Correr-Sobrinho L, Muniz L, Mathias P. Effect of different adhesion strategies on fiber post cementation: push-out test and scanning electron microscopy analysis. Contemp Clin Dent. 2013 Oct;4(4):443-7. http://dx.doi.org/10.4103/0976-237X.123022. PMid:24403786. 
21. Lindblad RM, Lassila LV, Salo V, Vallittu PK, Tjäderhane L. Effect of chlorhexidine on initial adhesion of fiber-reinforced post to root canal. J Dent. 2010 Oct;38(10):796-801. http://dx.doi.org/10.1016/j.jdent.2010.06.011. PMid:20600556.

22. Collares FM, Rodrigues SB, Leitune VC, Celeste RK, Borba de Araújo F, Samuel SM. Chlorhexidine application in adhesive procedures: a meta-regression analysis. J Adhes Dent. 2013 Feb;15(1):11-8. http://dx.doi.org/10.3290/j.jad.a28732. PMid:23534018.

23. Leitune VCB, Collares FM, Werner Samuel SM. Influence of chlorhexidine application at longitudinal push-out bond strength of fiber posts. Oral Surg Oral Med Oral Pathol Oral Radiol Endod. 2010 Nov;110(5):e77-81. http://dx.doi.org/10.1016/j.tripleo.2010.04.046. PMid:20692186.

24. Martinho FC, Carvalho CA, Oliveira LD, Lacerda AJ, Xavier AC, Augusto MG, et al. Comparison of different dentin pretreatment protocols on the bond strength of glass fiber post using self-etching adhesive. J Endod. 2015 Jan;41(1):83-7. http://dx.doi.org/10.1016/j.joen.2014.07.018. PMid:25246368.

25. Research Randomizer [Internet]. 2018 [cited 2018 Feb 20]. Available from: https://www.randomizer.org/about/

26. Souza AC, Gonçalves FC, Anami LC, Melo RM, Bottino MA, Valandro LF. Influence of insertion techniques for resin cement and mechanical cycling on the bond strength between fiber posts and root dentin. J Adhes Dent. 2015 Apr;17(2):175-80. http://dx.doi.org/10.3290/j.jad.a33993. PMid:25859568.

27. Di Hipólito V, Rodrigues FP, Piveta FB, Azevedo LC, Bruschi Alonso RC, Silikas N, et al. Effectiveness of self-adhesive luting cements in bonding to chlorhexidine-treated dentin. Dent Mater. 2012 May;28(5):495-501. http://dx.doi.org/10.1016/j.dental.2011.11.027. PMid:22204915.

28. Misra DN. Interaction of chlorhexidine digluconate with and adsorption of chlorhexidine on hydroxyapatite. J Biomed Mater Res. 1994 Nov;28(11):1375-81. http://dx.doi.org/10.1002/jbm.820281116. PMid:7829568.

29. Angeloni V, Mazzoni A, Marchesi G, Cadenaro M, Comba A, Maravi T, et al. Role of chlorhexidine on long-term bond strength of self-adhesive composite cements to intraradicular dentin. J Adhes Dent. 2017;19(4):341-8. http://dx.doi.org/10.3290/j.jad.a38896. PMid:28849803.

30. Mendes M, França FMG, Basting RT, Turssi CP, Amaral FLB. Long term bond strenght of fiber posts cement to dentin self-adhesive or conventional resin cements. J Adhes Sci Technol. 2017;31(9):977-87. http://dx.doi.org/10.1080/01694243.2016.1238124.

31. Park JS, Lee JS, Park JW, Chung WG, Choi EH, Lee Y. Comparison of push-out bond strength of fiberreinforced composite resin posts according to cement thickness. J Prosthet Dent. 2017 Sep;118(3):372-8. http://dx.doi.org/10.1016/j.prosdent.2016.11.007. PMid:28222875.

\section{CONFLICTS OF INTERESTS}

The authors declare no conflicts of interest.

\section{${ }^{*}$ CORRESPONDING AUTHOR}

Tainara Conte, Rua Economia, 699, apartamento 13, Bairro Universitário, 85819-110 Cascavel - PR, Brasil, e-mail: tainaraconte@hotmail.com

Received: March 9, 2019

Accepted: October 2, 2019 